and the author then proceeds to quote solutions for various inputs. The examplos of lateral response are particularly lengthy. All the appropriate references are given, but I would have preferred a more detailed troatment of the basic mathematics, particularly since more elementary matters (for example, estimation of derivatives) are expounded at some length.

The third part, "Stability and Design", deals with various practical matters, including a very useful detailed example of stability calculations for a subsonic fighter. There are several excellent appendixes. The standard of production of the book is high and the diagrams are generally clear without being outstandingly elegant.

To summarize: this book is an invaluable compendium of information. Naturally, there are some omissions (for example, time-vector methods) and missiles are not specifically mentioned. One might have expected perhaps a slightly more selective approach to the sources used, but this is largely a matter of personal preference. All concerned with aircraft stability will find it well worth having.

F. G. IRVING

\section{THE CURATE'S EGG}

\section{Sedimentary Petrography}

With Special Reference to Petrographic Methods of Correlation of Strata, Petroleum Technology and other Economic Applications of Goology. By Henry B. Milnor. Co-editors: Dr. A. M. Ward and Frank Higham. Vol. I: Methods in Sedimentary Petrography. Pp. $643+25$ plates. Vol. II: Principles and Applications. Pp. $715+71$ plates. (London : George Allen and Unwin, Ltd., 1962.) $100 s$. net each volume.

$\mathrm{T}^{\mathrm{T}}$ is with mixed feelings that one writes of this long. I awaited and much-needed new edition of Milner's Sedimentary Petrography for, like the proverbial curate's egg, it is 'good in parts'. In other parts the standard is no higher than that of the 1929 edition and much of the data are no more recent.

Volume $I$ is good. The introduction gives an excellent survey of the study of sedimentary rocks from an unusual angle - a regional one. Most of tho material is now and well worth publishing in the present form. There are invaluable and very complete details of techniques and methods of work which are useful both to the academic research worker and to those engaged in economic geology. The standard of the volume is high, possibly because this side of geology interests the author most. It is regretted that so unsatisfactory an apparatus as the sedimentation balance should be included. A more modern approach to particle size analysis is needed and an account of oscillographic methods should have been given. Also, in the account of the optical study of minerals, it is a pity that a book of this standard should perpetuate a rule-of-thumb method of finding optic signs. To derive these from first principles is more instructive and valuable to the student. That glauconite should be classed as "Amorphous (Noncrystalline)" with "no variation in directional properties" is a direct contradiction of the details given on pp. 111 and 319 in Volume II. The bibliography, though incomplete, is good, but unfortunately does not go beyond 1957.

Volume II, with the formula of some minerals out of date, with spelling mistakes such as "sanadine" and "dentritic" rather common, with a definition of greywacko no more recent than 1935, and much of the material word for word as in the 1929 edition, comes as an anticlimax. Chapters 3 and 7 save the day and Chapter 8 on applied potrology is much improved. But it is a pity that the sulphates and nitrates of Plate 57 should have been placed opposite the first page on clay minerals. The general standard of the plates is deplorable. Those which in the earlier editions were excellent are still good; those which were bad are still bad. Some of the new ones are worse; indeed, they are virtually useless, and this in spite of the improvoments in photographic techniques and instruments. Brammall's brush drawings and Smithson's wash drawings put them to shame. A major weakness of the earlier editions, Chapter 5, is still with us. Such casehistories would be more rolevant and interesting if the foreign examples were replaced by British. Plates 63, 64 and 65 serve no useful purpose. The bibliographios are excellent.

Unfortunately, the appendixes to the new Volume II no longer include determinative tables based on optical properties. Useless appendages such as Appendixes I or VII could have been omitted with advantage.

\section{P. S. WALDER}

\section{LABORATORY ORGANIZATION}

\section{Laboratory Organization and Administration}

By K. Guy. Pp. xiv + 386. (London: Macmillan and Co.. Ltd. ; New York : St. Martin's Press, Inc., 1962.) 50s. net.

W HEN faced with the design of new laboratories, it is necessary to spend a groat deal of time in careful thought and in recalling all the details associated with each function of the laboratories in question. This book will help to save time becauso the various factors to be considered are all set out clearly. It is indeed a good aide memoire.

As the author explains, tho higher aspects of management are not discussed but a considerable amount of space is given to stores management, including buying, stockkeeping, as well as regulations concerning dangerous materials and their handling. It is surprising, however, that in discussing the layout of shelving in stores, no mention is made of the type of space-saving system based on the use of mobile shelving.

A great deal of space is devoted, as it should be, to the designing of laboratories and tho materials of construction of bench tops, drains, floors, etc. Time-honoured toak holds pride of place for bench tops, but it is good to see that stainless steel is accorded a high rating. Laminated plastics, however, are regarded as having achieved a greater usage than thoir properties warrant. Among flooring materials, a notable omission is that of poured plastic, so usoful in sterile areas.

The chapter on laboratory inspection and maintenance is both useful and informative, and so is the chapter on "Safety in the Laboratory and Workshop" (65 pages), which covers all the usual hazards and their countermeasures, as well as the first-aid required to deal with laboratory accidents. In the same chapter, account is taken of the problems associated with radioactive materials, X-rays, otc.

The author's interest in optical projection on one hand and the filing of laboratory rocords and technical information on the other is obvious from two excellent chapters on these aspects of the roquirements of teaching labora. tories. Finally, there is an extensive bibliography.

The fact that the requirements of specialized laboratories concerned with bacteriology, pharmacology, animal breeding, etc., are not specifically considered is, gonorally speaking, of secondary importance.

This book is written with its possible use as a course in the syllabuses for the examinations of laboratory technicians very much in mind, but the fact that it encompasses such a vast amount of information on laboratory management and design will ensure it a place on the sholves of anyone who is likely to be engaged in setting up new laboratories or extending old ones, if only to keep them reminded of the thousand and one items that have to be remembered if costly mistakes are to be avoided.

F. H. Milner 